\title{
Correlation Between Personal Hygiene And Hemoglobin Levels On Typhoid Fever Suspect Patients At Lirboyo General Hospital
}

\section{Hubungan Personal Hygiene Dengan Kadar Hemoglobin Pada Penderita Suspek Demam Tifoid Di Rumah Sakit Umum Lirboyo}

\author{
Indana Farodis*, Mely Purnadianti \\ Prodi Teknologi Laboratorium Medis, Fakultas Sains, Teknologi \& Analisis, Institut IImu Kesehatan Bhakti Wiyata \\ Kediri, Jl. KH Wachid Hasyim No.65, Bandar Lor, Kec. Mojoroto, Kediri,64114, Jawa Timur, Indonesia
}

Personal Hygiene is an effort made by individuals in maintaining personal hygiene to avoid disease. Personal Hygiene is closely related to typhoid fever, because its transmission can be through food and drinks which are contaminated with Salmonella typhi. WHO and UNICEF on 2015 ranked Indonesia as the second worst sanitation country in the world after India. One of the laboratory tests which is used to observe anemia levels and polycythaemia is hemoglobin degree. The purpose of this study was to analyze the correlation between personal hygiene and hemoglobin levels on typhoid fever suspect patients at Lirboyo General Hospital. The research method used analytic survey with Cross Sectional Study approach and purposive sampling used as the sampling technique with 38 respondents. The results of the study mostly have worst personal hygiene quality of 31 people (81.6\%) while respondents have good personal hygiene quality of 7 people (18.4\%) and the of hemoglobin category on patients stated normal in 29 people $(76.3 \%)$ while patients who have abnormal hemoglobin category in 9 people $(23.7 \%)$. Based on statistical tests on personal hygiene by hemoglobin showed $0.876 \mathrm{p}$-value and $>0.05 \mathrm{sig}$ value Conclusion which indicated no correlation between personal hygiene and hemoglobin on typhoid fever suspect at Lirboyo General Hospital.

Keywords: hemoglobin, personal hygiene, typhoid fever suspect

Personal hygiene adalah suatu upaya yang dilakukan oleh individu dalam menjaga kebersihan pribadi agar terhindar dari penyakit. Personal hygiene sangat erat kaitannya dengan penyakit demam tifoid karena penularannya dapat terjadi melalui makanan dan minuman yang terkontaminasi oleh bakteri Salmonella typhi. WHO dan UNICEF ada tahun 2015 menempatkan Indonesia sebagai negara dengan 
sanitasi terburuk kedua di dunia setelah India. Salah satu pemeriksaan laboratorium yang digunakan untuk melihat tingkat anemia dan polisitemia adalah kadar hemoglobin. Tujuan: penelitian ini adalah untuk menganalisis hubungan personal hygiene dengan kadar hemoglobin pada penderita suspek demam tifoid di Rumah Sakit Umum Lirboyo. Metode penelitian dengan menggunakan survey analitik dengan pendekatan Cross Sectional Study dan tekhnik sampling yang digunakan adalah purposive sampling dengan jumlah sampel sebanyak 38 responden. Hasil penelitian ini sebagian besar memiliki kualitas personal hygiene yang tidak baik sebanyak 31 orang $(81,6 \%)$ sedangkan responden yang mempunyai kualitas personal hygiene yang baik adalah 7 orang $(18,4 \%)$ dan kategori hemoglobin pada pasien menyatakan normal sebanyak 29 orang (76,3\%) sedangkan pasien yang mempunyai hemoglobin tidak normal sebanyak 9 orang $(23,7 \%)$. Berdasarkan uji statistik pada personal hygiene dengan hemoglobin menunjukkan nilai $p$-value 0,876 yang berarti nilai sig. $>0,05$. Kesimpulan dari penelitian ini adalah tidak ada hubungan personal hygiene dengan kadar hemoglobin pada pasien suspek demam tifoid di Rumah Sakit Umum Lirboyo.suspek demam tifoid di Rumah Sakit Umum Lirboyo.

Kata Kunci: hemoglobin, personal hygiene, suspek demam tifoid 


\section{PENDAHULUAN}

Personal hygiene adalah suatu upaya yang dilakukan oleh individu dalam menjaga kebersihan pribadi agar terhindar dari penyakit Alimul (2006). Personal Hygiene sangat erat kaitannya dengan penyakit demam tifoid karena penularannya dapat terjadi melalui makanan dan minuman yang terkontaminasi oleh bakteri Salmonella typhi dan dapat juga dengan melalui tangan atau kuku yang kotor, sehingga dimungkinkan terselip bakteri di dalamnya serta berpotensi akan tertelan ketika makan Suraya and Atikasari (2019). Upaya peningkatan personal hygiene sampai saat ini belum menunjukkan hasil yang optimal, hal ini antara lain dapat dilihat dari data hasil penelitian yang dilakukan oleh Suraya and Atikasari (2019) menunjukkan bahwa anak yang mengalami kejadian demam tifoid dan memiliki personal hygiene yang kurang sebanyak 7 orang $(58,3 \%)$ lebih banyak dibandingkan dengan responden yang memiliki personal hygiene baik yaitu sebanyak 3 orang $(13,0 \%)$. Kebersihan perorangan atau personal hygiene sangat erat kaitannya dengan sanitasi lingkungan. WHO dan UNICEF pada tahun 2015 menempatkan Indonesia sebagai negara dengan sanitasi terburuk kedua di dunia setelah India. Hal ini sangat ironis jika dibandingkan dengan negara-negara di kawasan Asia Tenggara seperti Singapura dan Malaysia yang mencapai cakupan layanan sanitasi diatas $90 \%$ World Health Organization (WHO).

Data World Health Organization (WHO) menunjukkan jumlah kasus demam tifoid di seluruh dunia mencapai 17 juta per tahun dengan 600.000 orang meninggal dan $70 \%$ kematiannya terjadi di Asia. Diperkirakan angka kejadian dari 150/100.000 per tahun terjadi di Amerika Serikat dan 900/100.000 kasus per tahun di Asia Paputungan (2016).

Menurut survei yang dilakukan oleh Departemen Kesehatan Indonesia pada tahun 2013 di berbagai Rumah Sakit di seluruh Indonesia dari tahun 2008-2013 menunjukkan peningkatan jumlah penderita demam tifoid sekitar 35,8\% yaitu dari 19.596 menjadi 26.606 kasus. Pada tahun 2015 kasus demam tifoid menempati urutan ketiga dari data 10 penyakit utama pasien rawat inap rumah sakit dengan jumlah pasien sebanyak 41 orang Syahrulachman (2010).

Insiden kejadian demam tifoid di Provinsi Jawa Timur menunjukkan angka kematian sebesar $0,8 \%$, dengan proporsi 4000 dan 1000 kasus per bulan yang terjadi di Puskesmas dan Rumah Sakit. Selama masa periode 5 tahun (1991-1995), di RSUD dr. Sutomo Surabaya telah dirawat sebanyak 586 penderita demam tifoid dengan angka kematian 1,4\% dan periode 5 tahun kemudian (1996-2000), telah dirawat sebanyak 1.563 penderita demam tifoid dengan mortalitas 1,09\% Soewondo (2002).

Menurut Ardiantus (2016) di dalam penelitiannya mengatakan "Data dari Dinas Kesehatan Kota Kediri pada tahun 2015 - 2016, didapatkan kasus klinis demam tifoid sebanyak 908 orang, sedangkan jumlah orang yang positif pada pemeriksaan widal adalah 158 orang". Pada penelitian di Rumah Sakit Medika Lestari Ciledug didapatkan bahwa hygiene personal yang kurang baik dan masih banyak warga kurang berprilaku hidup sehat seperti kuku jari tangan dan kaki yang tidak terpotong pen- dek serta kotor, tidak mencuci tangan dengan air bersih yang mengalir, tidak menggosok sela - sela jari dan kuku tangan sehingga bakteri Salmonella typhi masih ada di bagian tubuh Suraya and Atikasari (2019). Pemeriksaan hemoglobin dalam darah mempunyai peranan penting dalam diagnosis suatu penyakit. Kegunaan dari pemeriksaan kadar hemoglobin adalah untuk menilai tingkat anemia, atau perkembangan penyakit yang berhubungan dengan anemia dan polisitemia. Anemia ditentukan oleh penurunan kadar hemoglobin dalam darah dibawah nilai normal, pada pria dewasa kadar hemoglobin kurang dari 13,5 g/dL dan kurang dari 11,5 g/dL pada wanita dewasa Bakta (2006). Polisitemia adalah peningkatan kadar hemoglobin melebihi batas atas rentang nilai normal, yaitu pada pria $\mathrm{Hb}>18,5 \mathrm{~g} / \mathrm{dl}$ dan wanita

$>16,5 \mathrm{~g} / \mathrm{dl}$ Hoffbrand and Moss (2013).

Berdasarkan observasi yang penulis lakukan pada saat studi pendahuluan di Rumah Sakit Umum Lirboyo pada tanggal 2 sampai dengan 4 Oktober 2019, didapatkan prevelensi penyakit tertinggi yaitu demam tifoid. Angka kejadian kasus demam tifoid pada 3 bulan terakhir di Rumah Sakit Umum Lirboyo yaitu 188 pasien. Timbulnya masalah yang dihadapi dalam penyakit ini adalah masyarakat yang kurang memperhatikan pola hidup bersih dan sehat. Hal ini dapat memicu adanya bakteri Salmonella typhi yang kemudian dengan cara oral atau melewati makananan dan minuman akan masuk kedalam tubuh dan pada akhirnya akan mengakibatkan penurunan kadar hemoglobin dan dapat mengindikasi terjadinya anemia. Berdasarkan latar belakang tersebut, maka penulis terdorong untuk menganalisis hubungan personal hygiene dengan kadar hemoglobin pada penderita suspek demam tifoid di Rumah Sakit Umum Lirboyo.

\section{METODE}

Penelitian ini menggunakan survei analitik dengan metode observasional serta pendekatan cross sectional study dan teknik sampling yang digunakan adalah purposive sampling yaitu suatu teknik penentuan sampel dengan menggunakan pertimbangan tertentu. Penelitian dilakukan di Rumah Sakit Umum Lirboyo yang beralamat di Jalan. Dr Saharjo, RT.01/RW.02, Mojoroto, Campurejo, Kecamatan Kediri, Jawa Timur pada bulan Maret s.d Mei 2020. Jumlah sampel yang digunakan dalam penelitian ini adalah sebanyak 38 sampel. Analisis data statistika menggunakan uji chi square dengan software SPSS IBM 23.

\section{HASIL DAN PEMBAHASAN}

Dari hasil penelitian yang diperoleh, pembahasan dilakukan untuk mengetahui tentang hubungan personal hygiene den gan kadar hemoglobin di Rumah Sakit Umum Lirboyo. 
TABLE 1 / Karakteristik Jenis Kelamin Pasien

\begin{tabular}{lll}
\hline Jenis & Frekuensi & $\%$ \\
Laki-Laki & 16 & 42,1 \\
Perempuan & 22 & 57,9 \\
Total & 38 & 100 \\
\hline
\end{tabular}

TABLE 2 / Karakteristik Usia Pasien

\begin{tabular}{lll}
\hline Usia & Frekuensi & $\%$ \\
$12-14$ & 10 & 26,3 \\
$>15$ tahun & 28 & 73,7 \\
Total & 38 & 100 \\
\hline
\end{tabular}

TABLE 3 / Kualitas Personal Hygiene Pasien

\begin{tabular}{lll}
\hline Kategori & Frekuensi & $\%$ \\
Baik & 7 & 18,4 \\
Tidak baik & 31 & 81,6 \\
Total & 38 & 100 \\
\hline
\end{tabular}

TABLE 4 / Kadar Hemoglobin Pasien

\begin{tabular}{lll}
\hline Kategori & Frekuensi & $\%$ \\
Normal & 29 & 76,3 \\
Tidak & 9 & 23,7 \\
Total & 38 & 100 \\
\hline
\end{tabular}

TABLE 5 / Hasil Uji Statistik

\begin{tabular}{|c|c|c|c|c|}
\hline & & Hemoglobin & & \\
\hline & & Normal & Tidak Normal & P-value \\
\hline \multirow{3}{*}{ Personal Hygiene } & Baik & 6 & 1 & \\
\hline & & $(85,7 \%)$ & $(14,3 \%)$ & 0,0875 \\
\hline & Tidak Baik & $\begin{array}{l}23 \\
(74,2 \%)\end{array}$ & $\begin{array}{l}8 \\
(25,8 \%)\end{array}$ & \\
\hline Total & & $\begin{array}{l}29 \\
(76,3 \%)\end{array}$ & $\begin{array}{l}9 \\
(23,7 \%)\end{array}$ & \\
\hline
\end{tabular}

Hasil penelitian berdasarkan jenis kelamin pada Tabel $\mathbf{1}$ didap- atkan hasil dari 38 responden yaitu jumlah pasien perempuan sebanyak 22 orang $(57,9 \%)$ sedangkan pasien lakilaki yaitu 16 orang $(42,1 \%)$. Hal ini sejalan dengan penelitian Gultom et al. (2006) didapatkan hasil bahwa jumlah pasien dengan jenis kelamin perempuan 149 orang $(57,5 \%)$ lebih banyak dari pada laki-laki 110 orang (42,5\%). Namun berbeda dengan peneli- tian yang dilakukan oleh Melarosa et al. (2019) didapatkan jenis kelamin laki-laki 36 orang $(65,5 \%)$ lebih banyak dari pada pasien perempuan 19 orang $(34,5 \%)$. Rusmana et al. (2013) didalam penelitiannya mendapatkan bahwa dari 30 responden jumlah pasien dengan jenis kelamin laki-laki dan perempuan adalah 1:1, perbedaan ini tentu dapat terjadi dikarenakan jum- lah responden yang digunakan dalam penelitian tidak sama, Menurut Choirunnisa et al. (2014) dalam penelitiannya meny- atakan bahwa antara laki-laki dan perempuan mempunyai resiko yang sama untuk terinfeksi demam tifoid.

Hasil penelitian berdasarkan usia pada Tabel $\mathbf{2}$, dari 38 pasien didapatkan hasil bahwa pasien yang berusia 1214 tahun adalah 10 orang $(26,3 \%)$ dan pasien yang berusia $>15$ tahun adalah 28 orang $(73,7 \%)$. Hal ini sejalan dengan penelitian Rakhman et al. (2009) yang menyatakan bahwa distribusi usia responden demam tifoid terbanyak pada usia $>15$ tahun dengan proporsi usia 16-20 tahun dengan jumlah 29 orang $(22,31 \%)$ dan pada usia $21-25$ tahun sebanyak 59 orang $(45,38 \%)$. Prevalensi demam tifoid yang tinggi ini dapat dikarenakan pada usia tersebut orang-orang cenderung memiliki aktivitas fisik yang banyak serta kurangnya menjaga pola makan dan dapat mengakibatkan mereka terkadang makan atau jajan di luar rumah dan disembarang tempat yang kurang menjaga higienitas. Bakteri Salmonella typhi terdapat didalam makanan yang kurang menjaga hygienitas dan hal ini dapat mengakibatkan tertularnya penyakit demam tifoid Anggraini (2012) ; Nurvina (2012).

Hasil penelitian berdasarkan kualitas personal hygiene pada Tabel 3 didapatkan pasien dengan kategori personal hygiene baik adalah sebanyak 7 orang $(18,4 \%)$ dan personal hygiene yang tidak baik adalah 31 orang $(81,6 \%)$. Menurut Maharani and Yusiana (2013) secara teoritis personal hygiene adalah suatu usaha yang dilakukan oleh individu dalam menghindari terjadinya suatu penyakit, salah satu kegiatan yang seharusnya diperhatikan yaitu pengolahan makanan untuk menghindari adanya kontaminasi yang dapat dilakukan dengan cuci tangan, menjaga kesehatan dan kebersihan diri. Mencuci tangan merupakan kegiatan yang mudah 
dan murah yang dapat dilakukan untuk mengendalikan risiko terjadinya penyakit. Hasil survei yang dilakukan oleh Health Service Program terdapat 98 dari 100 orang di Indonesia yang tidak mencuci tangan pakai sabun setelah buang air besar, sehingga banyak masyarakat Indonesia yang terkena penyakit saluran cerna dikarenakan gaya hidup yang tidak bersih Ris nawaty (2016) . Penelitian yang dilakukan oleh Silalahi and Putri (2017) tentang keterkaitan karakteristik keluarga dengan personal hygiene anak sekolah dasar, didapatkan hasil bahwa sebagian besar responden memiliki personal hygiene yang tidak baik.

Hasil penelitian berdasarkan hemoglobin pada Tabel 4 maka didapatkan bahwa pasien dengan kadar hemoglobin normal sebanyak 29 orang $(76,3 \%)$ sedangkan pasien dengan kadar hemoglobin tidak normal sebanyak 9 orang $(23,7 \%)$. Hasil penelitian ini serupa dengan penelitian yang dilakukan oleh Rusmana et al. (2013) tentang gambaran gejala klinik, hemoglobin, trombosit dan uji widal pada penderita demam tifoid dengan IgM anti Salmonella typhi (+) di dua Rumah Sakit Subang tahun 2013 dan didapatkan hasil bahwa pasien yang mempunyai hemoglobin normal sebanyak 12 orang (40\%) dan yang menderita anemia sebanyak 8 orang $(26,7 \%)$. Anemia yang terjadi dapat dikarenakan salmonella typhi dapat menginvasi ke organ hematopoitik seperti nodus limfatikus, lien, tonsil, sumsum tulang atau lainnya, sehingga dapat terjadinya depresi hematopoises dan menyebabkan anemia atau penurunan kadar hemoglobin dengan gejala klinis yang sering dikeluhkan yaitu demam dan gastrointestinal Okafor (2007). Berdasarkan critical values yag dikeluarkan oleh Rumah Sakit Umum Daerah Dr Soedono Madiun. Nilai kritis dari pemeriksaan hemoglobin dan dapat dikatakan anemia adalah ketika nilai hemoglobin $<7 \mathrm{~g} / \mathrm{dl}$ dan dikatakan polisitemia atau peningkatan kadar hemoglobin adalah $>20 \mathrm{~g} / \mathrm{dl}$. Sedangkan menurut Bakta (2006) klasifikasi anemia yang dipakai yaitu anemia ringan $(\mathrm{Hb} 10 \mathrm{~g} / \mathrm{dl}$ - kurang dari nilai normal), anemia sedang ( $\mathrm{Hb} 6-7,9 \mathrm{~g} / \mathrm{dl})$, anemia berat $(<6 \mathrm{~g} / \mathrm{dl})$. Dalam hal ini dapat ditarik sebuah hasil bahwa klasifikasi anemia dalam penelitian ini termasuk anemia ringan.

Penilaian karakteristik personal hygiene pasien dari cara mencuci tangan dengan air mengalir dan sabun yaitu dikategorikan tidak baik dengan presentase terbanyak pada butir mencuci tangan menggunakan sabun sebelum makan yaitu sebanyak 23 orang $(60,6 \%)$. Berdasarkan dari hasil penelitian yang telah dilakukan, sebagian besar dari pasien pada penelitian ini merupakan santri dari pondok pesantren Lirboyo dan pada saat hendak makan mereka hanya mencuci tangan dengan air saja tidak menggunakan sabun bahkan ada beberapa yang menyatakan bahwa responden tidak mencuci tangan pada saat akan makan.Kebiasaan mencuci tangan dengan air saja tidak dapat melindungi tubuh dari bakteri penyebab penyakit yang ada di tangan. Terlebih apabila jika mencuci tangan tidak dibawah air mengalir dan berbagi wadah cuci tangan dengan orang lain. Hal ini akan menyebabkan bakteri yang menempel pada tangan dapat masuk kedalam tubuh baik secara langsung apabila tangan memegang bagian hidung, mata dan mulut atau secara tidak langsung dengan melalui makanan minuman yang tercemar oleh bakteri Salmonella typhi RI (2014) ; Lestari et al. (2017). Selain itu, menurut Irawati (2000) mencuci tangan merupakan salah satu faktor determinan status anemia. Anak yang rajin mencuci tangan ternyata mempunyai resiko yang lebih kecil untuk terkena anemia.

Penilaian karakteristik personal hygiene pasien dari cara pengolahan makanan yaitu dikategorikan tidak baik dengan presentase terbanyak pada butir mencuci sayuran, buahbuahan dan bahan makanan dengan air mengalir yaitu sebanyak 35 orang $(92,1 \%)$. Menurut (WHO), menyatakan bahwa mencuci sayuran sebelum memasak dengan air mengalir merupakan suatu hal yang sebaiknya dilakukan sebab mencuci dengan air dalam satu wadah atau tidak mencuci sayuran adalah hal yang sangat beresiko tinggi terkontaminasi bakteri, begitu pula dengan buah-buahan yang dianjurkan mencucinya terlebih dahulu sebelum dikonsumsi. Sayuran segar dan buah-buahan bisa saja terkontaminasi mikroorganisme atau zat kimia, oleh sebab itu sayuran mentah atau buahbuahan harus dicuci terlebih dahulu, baik untuk dimakan langsung atau sebelum dimasak.

Penilaian karakteristik personal hygiene pasien dari kebersihan tubuh dan kuku yaitu dikategorikan baik. Pasien yang kukunya tidak terpotong pendek sebanyak 13 orang $(34,2 \%)$ sementara yang tidak mandi sebanyak $2 \mathrm{X}$ sehari adalah sebanyak 14 orang (36,8\%). Menurut penelitian yang dilakukan oleh Suraya and Atikasari (2019) kuku atau tangan yang kotor dapat memungkinkan terselipnya bakteri dan akan berpotensi tertelannya bakteri tersebut bersama makanan ketika makan. Kondisi ini akan semakin diperparah jika tidak terbiasa mencuci tangan menggunakan sabun sebelum makan.

Berdasarkan Tabel 5 dapat diketahui bahwa dari 38 orang pasien dengan personal hygiene baik dan menderita anemia sebanyak 1 orang $(14,3 \%)$, sedangkan pasien yang kualitas personal hygiene tidak baik dan mempunyai kadar hemoglobin normal sebanyak 23 orang $(74,2 \%)$. Setelah dilakukan pengujian hipotesa dengan menggunakan uji chi square maka didapatkan hasil p-value sebesar 0,876 yang berarti tidak ada hubungan antara personal hygiene dengan hemoglobin di Rumah Sakit Umum Lirboyo.

Jaya and Romadilah (2013) didalam penelitiannya menyatakan normal tidaknya hemoglobin tidak selalu disebabkan oleh personal hygiene, tetapi dapat pula disebabkan oleh pola makan seseorang, sehingga walaupun individu dengan personal hygiene yang tidak baik namun orang tersebut mempunyai pola makan yang sehat dan bergizi maka akan menyebabkan kadar hemoglobin normal. Moehji (2009) menyatakan bahwa umumnya anemia disebabkan karena kurangnya asupan yang mengandung zat besi serta unsur-unsur lainnya yang sangat diperlukan sel darah merah diantaranya adalah asam folat, vitamin B12, vitamin C, riboflavin dan tembaga. Dengan demikian kemungkinan anemia lebih banyak disebabkan karena pola makan seseorang serta anemia tidak selalu disebabkan oleh personal hygiene melainkan juga dapat dipengaruhi oleh pola makan yang sehat dan adekuat. 


\section{KESIMPULAN}

1. Kualitas personal hygiene pada penelitian ini mempunyai personal hygiene yang tidak baik sebanyak 31 orang $(81,6 \%)$.

2. Kadar hemoglobin pada penelitian ini adalah normal sebanyak 29 orang $(76,3 \%)$.

3. Tidak ada hubungan antara personal hygiene dengan kadar hemoglobin pada penderita suspek demam tifoid di Rumah Sakit Umum

\section{KONTRIBUSI PENULIS}

Penulis pertama berperan utama dalam pengumpulan data, sedangkan penulis kedua membantu dalam penyusunan artikel.

\section{PENDANAAN}

Dana penelitian berasal dari dana mandiri peneliti.

\section{UCAPAN TERIMA KASIH}

Terimakasih kepada segenap pihak yang telah membantu dalam penelitian ini.

Paputungan, W. (2016). Hubungan Antara Perilaku Hidup Bersih Dan Sehat Dengan Kejadian Demam Tifoid di Wilayah Kerja Puskesmas Upai Kota Kota- mobagu Tahun 2015. PHARMACON 5, 266-275.

Alimul, A. (2006). Pengantar Kebutuhan Dasar Manusia (Jakarta: Salemba Medika).

Anggraini, H. (2012). Faktor-Faktor Yang Berhubungan Dengan Kejadian Demam Tifoid Pada Anak Yang Dirawat Di RSUD Dr. H. Soemarmo Sostroatmodjo Kabupaten Kapuas Provinsi Kalimantan Tengah Pada Tahun 2012.

Ardiantus, A. (2016). Hubungan Hasil Pemeriksaan IgM Salmonella Metode Immunokromatografi Dengan Jumlah Limfosit Pada Penderita Suspek Demam Tifoid Di Rumah Sakit Baptis.

Bakta, M. (2006). Hematologi Klinik Ringkas (Jakarta: EGC).

Choirunnisa, N., Tjiptaningrum, A., and Basuki, W. (2014). Proporsi Pemeriksaan IgM Anti Salmonella Typhi 09 Positif Menggunakan Tubex Dengan Pemeriksaan Widal Positif Pada Pasien Klinis Demam Tifoid Akut di RSUD Dr. H. Abdul Moelek Bandar Lampung. Medical Faculty Of Lampung University 3, 102-110.

Gultom, M. D., Jemadi, and Rasmaliah (2006). Karakteristik Penderita

Demam Tifoid Yang Dirawat Inap Di Rumah Sakit Santa Elisabeth Medan

Tahun 2016.1, 1-10.

Hoffbrand, A. and Moss, H. (2013). Essential Haematology (Jakarta: EGC). Irawati (2000). Faktor Determinan Status Gizi Dan Anemia Murid SD Di Desa IDT Penerima PMT-AS di Indonesia laporan penelitian Rutin. Pusat Penelitian Dan Pengembangan Gizi (Jakarta: Badan Penelitian dan Pengembangan Kesehatan, Depkes RI.).

Jaya, I. K. S. and Romadilah (2013). Hubungan Infeksi Kecacingan dan Personal Hygiene Dengan kadar Hemoglobin Siswa SDN 51 Cakranegara Kota Mataram Tahun 2013. Media Bina IImiah 7, 1-7.

Lestari, Y., Nirmala, F., and Saktiansyah, L. O. A. (2017). Analisis Dampak Kepadatan Lalat, Sanitasi Lingkungan dan Personal Hygiene Terhadap Kejadian Demam Tifoid di Pemukiman UPTD Rumah Pemotongan Hewan (RPH) Kota Kendari Tahun. Jurnal IImiah Mahasiswa Kesehatan Masyarakat 2, 1-9. doi: 10.37887/jimkesmas.v2i6.2947.

Maharani, D. and Yusiana, M. A. (2013). Personal Hygiene lbu Yang Kurang Berhubungan Dengan Kejadian Diare Pada Balita Di Ruang Anak. Jurnal STIKES 6, 119-128.

Melarosa, P. R., Ernawati, D. K., and Mahendra, A. N. (2019). Pola Penggunaan Antibiotik Pada Psien Dewasa Dengan Demam Tifoid Di RSUP Sanglah Den- pasar Tahun 2016-2017. E-Jurnal Medika Udayana 8, 12-16.

Moehji, S. (2009). IImu Gizi (Jakarta: Papas Sinar Sinarti).

Nurvina (2012). Hubungan Antara sanitasi Lingkungan Hygiene Perorangan Dan Karakteristik Individu Dengan Kejadian Demam Tifoid Di Wilayah Kerja Puskesmas Kedungmundu Kota Semarang Tahun 2012.

Okafor, A. (2007). Haematological alterations due to typhoid fever in Enugu Urban- Nigeria. Malaysian Journal of Microbiology 3, 19-22. doi: $10.21161 / \mathrm{mjm} .01007$.
Rakhman, A., Humardewiyanti, R., and Pramono, D. (2009). Faktor-Faktor Risiko Yang Berpengaruh Terhadap Kejadian Demam Tifoid Pada Orang Dewasa. Berita Kedokteran Masyarakat 25, 167-175. doi: $10.22146 / \mathrm{bkm} .3550$.

RI, K. (2014). Profil Kesehatan Indonesia Tahun 2013 (Jakarta: Kementerian Kesehatan Republik Indonesia.).

Risnawaty, G. (2016). Faktor Determinan Perilaku Cuci Tangan Pakai Sabun (CTPS) Pada Masyarakat Di Tanah Kalikedinding. Jurnal Promkes 4, 70-81. doi: 10.20473/jpk.v4.i1.2016.70-81.

Rusmana, D., Sugiarto, C., and Pritanandi, R. H. (2013). Gambaran Gejala Klinik, Hemoglobin, Leukosit, Trombosit Dan Uji Widal Pada Penderita Demam Tifoid Dengan IgM Anti Salmonella typhi (+) Di Dua Rumah Sakit Subang Tahun 2013

Silalahi, V. and Putri, R. M. (2017). Keterkaitan Karakteristik Keluarga Dengan Personal Hygiene Anak Sekolah Dasar. Jurnal Care 5, 393-402. doi: 10.33366/cr.v5i3.840.

Soewondo, E. S. (2002). Seri Penyakit Tropik Infeksi Perkembangan Terkini dalam Pengelolaan beberapa Penyakit Tropik Infeksi. (Surabaya: Airlangga University Pers).

Suraya, C. and Atikasari, A. (2019). Hubungan Personal Hygiene dan Sumber Air Bersih Dengan Kejadian Demam Tifoid Pada Anak. Jurnal 'Aisyiyah Medika 4, 327-339. doi: 10.36729/jam.v4i3.205.

Syahrulachman (2010). Buku Ajar Mikrobiologi Kedokteran (Jakarta: Bina RupaAksara).

(WHO), W. H. O. (2006). Five Keys To Safer The Food Manual (Geneva: Department Of Food Safety WHO).

World Health Organization (WHO), U. (2015). Progress Drinking Water \& Sanitation (Swetzerland: WHO Press).

Conflict of Interest Statement: The authors declare that the research was conducted in the absence of any commercial or financial relationships that could be construed as a potential conflict of interest.

Copyright () 2020 Farodis and Purnadianti. This is an open-access article distributed under the terms of the Creative Commons Attribution License (CC BY). The use, distribution or reproduction in other forums is permitted, provided the original author(s) and the copyright owner(s) are credited and that the original publication in this journal is cited, in accordance with accepted academic practice. No use, distribution or reproduction is permitted which does not comply with these terms. 